\title{
Pemanfaatan Teknologi Firebase Dan Location Based Service Berbasis Android Sebagai Media Pemesan Makan Dan Minuman Pada Rumah Makan
}

\author{
Aang Alim Murtopo 1 \\ Email: aang.alim@gmail.com \\ TEKNIK INFORMATIKA STMIK YMI \\ Jl. Pendidikan No 1 Kota Tegal
}

\begin{abstract}
Abstrak
Teknologi smartphone sudah semakin berkembang dengan disediakannya berbagai platform. Salah satu platform yang sangat pesat adalah Android. Perkembangan tersebut mengakibatkan tingkat mobilitas menjadi sangat tinggi. Perkembatersebut menjadi satu hal yang harus di ikuti disemua bidang usaha. Hal yang sering dialami dalam kasus dipenelitian ini adalah keterlabatan dalam proses pesanan makan dan minuman yang berdampak kurangnya kepercayaan pelanggan. Melihat hal ini tujuan penelitian ini untuk menghasilkan aplikasi pemesanan makanan berbasis android agar memudahkan pelanggan melakukan proses pemesanan secara mandiri. Aplikasi yang dihasilkan memanfaatkan teknologi Firebase dan Location Based Service berbasis platform android dengan metode perancangan perangkat lunak System Development Life Cycle (SDLC). Aplikasi yang dirancangan dengan mempertimbangkan baik dari sisi pengguna maupun pengusaha rumah makan aplikasi yang dihasilkan berbasis android sehingga dalam proses pemesanan makan dan minuman bisa berjalan secara efektif dan maksimal.
\end{abstract}

Kata Kunci: Andoid, Firebase, Location Based Service, SDLC

\section{Pendahulan}

Ilmu pengetahuan dan teknologi saat ini berkembang sangat cepat, khususnya aplikasi pada smartphone. Teknologi smartphone juga sudah semakin berkembang dengan disediakannya berbagai platform. Salah satu platform yang sangat pesat adalah Android dimana rata - rata orang memilikinya. Dengan perkembangan tersebut mengakibatkan tingkat mobilitas menjadi sangat tinggi. Hal ini menjadi sangat diperhatikan oleh wirausahawan terutama di dunia kuliner yaitu di restoran atau di rumah makan untuk menyediakan fasilitas yang memudahkan konsumennya memesan makanan.

Location Based Service layanan informasi yang dapat diakses melalui mobile device dengan mengunakan mobile network, yang dilengkapi kemampuan untuk memanfaatkan lokasi dari mobile device tersebut. Layanan ini menggunakan teknologi global positioning system (GPS) dan cellbased location dari Google. Selain itu LBS tersebut terdiri dari beberapa komponen di antaranya mobile devices, communication network, position component, service dan content provider. Mobile devices merupakan komponen yang sangat penting. Piranti mobile tersebut diantaranya adalah smartphone, personal digital assistant (PDA) dan lainnya yang dapat berfungsi sebagai alat navigasi atau seperti halnya alat navigasi berbasis GPS.
Firebase mempunyai produk utama yaitu menyediakan database realtime dan backend sebagai layanan (Backend as a Service). Layanan ini menyediakan pengembang aplikasi API (Application Programming Interface) yang memungkinkan aplikasi data yang akan disinkronisasi di klien dan disimpan di cloud Firebase ini. Firebase menyediakan library untuk berbagai client platform yang memungkinkan integrasi dengan Android, Ios, JavaScript, Java, Objective-C dan Node aplikasi Js dan dapat juga disebut sebagai layanan DbaaS (Database as a Service) dengan konsep realtime. Dengan konsep realtime berbasis layanan cloud dengan backend sebagai service. Firebase digunakan untuk mempermudah dalam penambahan fitur fitur yang akan dibangun oleh developer.

Objek penelitian adalah Rumah Makan di wilayah Kabupaten Tegal yang mengusung rumah makan lesehan dan tempat duduk, dengan kreteria rumah makan tersebut mempunyai beberapa menu yang bervariasi, serta proses pemesanan makan menggunakan sistem konvensional dengan mencatat pesanan di selembar kertas, jika banyak pelanggan yang berkunjung, pelanggan yang selanjutnya harus menunggu pelayan selesai mencatat pesanan pelanggan pertama. Hal tersebut membuat pelayan kesulitan melayani pelanggan secara optimal, terkesan terburu - buru, dan mengakibatkan tulisan pelayan yang kadang tidak dapat dibaca, melihat permasalahan 
diatas maka dalam penelitian ini memfocuskan pada aplikasi berbasis android dengan memanfatkan teknologi firebase dan Location Based Service dengan metode SDLC

\section{Metode Penelitian}

Metode perancangan perangkat lunak menggunakan Metode SDLC (System Development Life Cycle) yang terdiri dari 6

System Development Lyfe Cycle (SDLC) merupakan keseluruhan proses dalam membangun sistem melalui beberapa langkah. Ada beberapa model SDLC. Model yang cukup populer dan banyak digunakan adalah waterfall. Beberapa model lain SDLC misalnya fountain, spiral, rapid, prototyping, incremental, build \& fix, dan synchronize \& stabilize.

Dalam sebuah siklus SDLC, secara umum terdapat enam langkah, berikut enam langkah siklusSDLC:

1. Analisis sistem, yaitu membuat analisis aliran kerja manajemen yang sedang berjalan

2. Spesifikasi kebutuhan sistem, yaitu melakukan perincian mengenai apa saja yang dibutuhkan dalam pengembangan sistem dan membuat perencanaan yang berkaitan dengan proyek sistem

3. Perancangan sistem, yaitu membuat desain aliran kerja manajemen dan desain pemrograman yang diperlukan untuk pengembangan sistem informasi

4. Pengembangan sistem, yaitu tahap pengembangan sistem informasi dengan menulis program yang diperlukan

5. Pengujian sistem, yaitu melakukan pengujian terhadap sistem yang telah dibuat

6. Implementasi dan pemeliharaan sistem, yaitu menerapkan dan memelihara sistem yang telah dibuat.

\section{Hasil dan Pembahasan}

\subsection{Pemodelan Bisnis}

Tahap ini dimana aliran informasi pada fungsi fungsi bisnis dimodelkan untuk mengetahui informasi apa yang mengendalikan proses bisnis, informasi apa yang dihasilkan, siapa yang membuat informasi itu, kemana saja informasi mengalir, dan siapa yang mengolahnya.

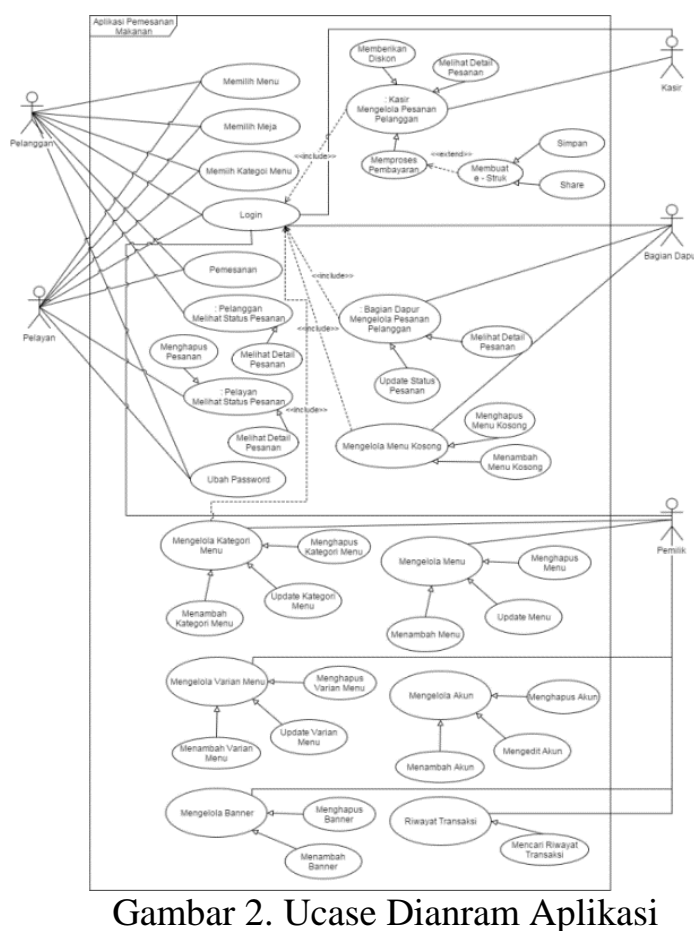

3.2. Deployment Diagram

Proses ini menggambarkan dimana hubungan antara software dan hardware secara spesifikasi bagaimana komponen perangkat lunak (artefak) digunakan pada komponen perangkat keras. Pada penelitian ini bisa terlihat pada gambar 3

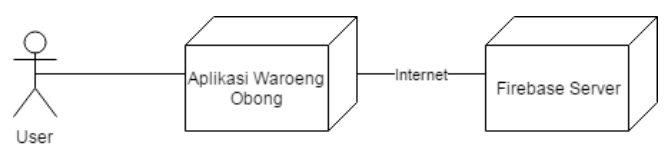

Gambar 3 Deployment Diagram

\subsection{User Interface Sistem}

a. Menu Login

Menu ini adalah tampilan awal pada sistem dimana ada 2 event yaitu masuk jika sudah punya akun dan daftar jika belum punya akun.

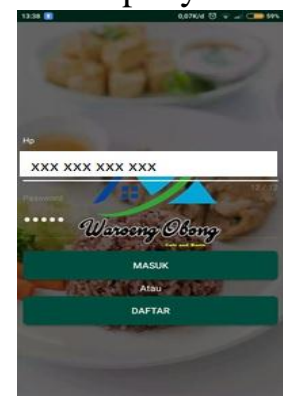

Gambar 4 Menu Login 
b. Menu Home Pelanggan

Tampilan pada menu home pelanggan menggambarkan dimana meja yang tersida sehingga pelanggan bisa memilih

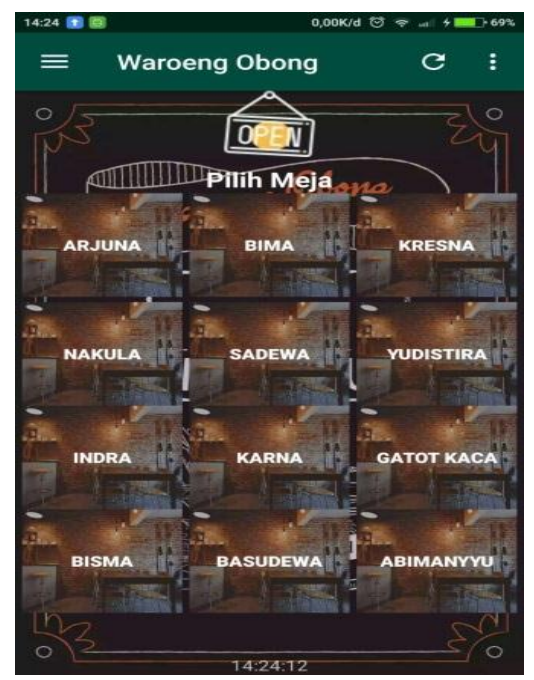

Gambar 5 Menu Home Pelanggan

c. Menu Bagian Dapur

Bagian menu ini terdiri dari 3 pilihan yapitu Home, Pesanan dan Menu Kosong. Pada menu ini bagian dapur dapat melihat makan yang telah dipesan oleh pelanggan.

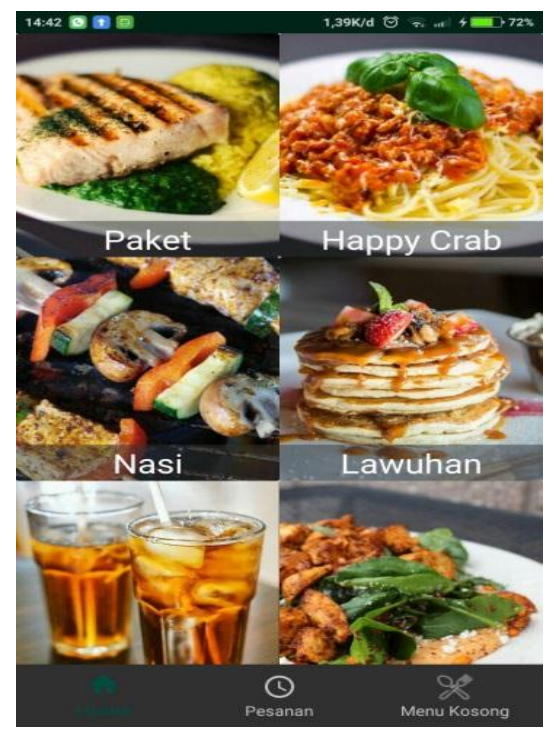

Gambar 6 Menu Bagian Daput

\section{d. Menu Kasir}

Pada menu kasir tersedia informasi pembayaran yang harus dilakukan oleh pelanggan, menu ini uga menginfor-masikan tentang diskon

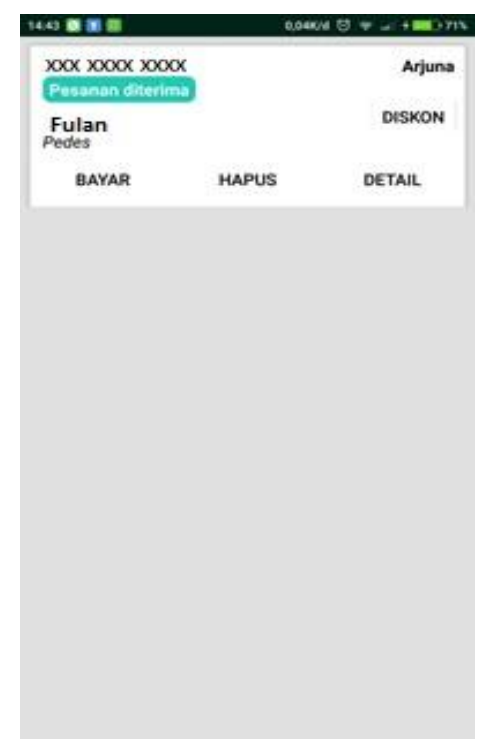

Gambar 7 Menu Kasir

\section{Kesimpulan}

Kesimpulan yang dapat di ambil dalam penelitian ini dapat dilihat sebagai berikut:

1. Aplikasi pemesanan makanan berbasis android bertujuan untuk mengganti sistem pemesanan manual yang kurang efektif dan efisien.

2. Aplikasi pemesanan makanan berbasis android ini dapat mengurangi penggunaan kertas yang berlebihan.

3. Dengan Aplikasi ini pelayanan dapat optimal apabila ada banyak pelanggan dalam satu waktu.

\section{Daftar Pustaka}

[1] M. Udka, R. R. Isnanto, and R. Kridalukmana, "Location Based Service Panduan Pencarian Rumah Sakit dengan Platform Android di Kota Semarang," J. Teknol. dan Sist. Komput., vol. 3, no. 2, p. 241, 2015.

[2] A. A. Indriani, Ratnawati, and F. Wanita, "Reminder Pengontrolan Perawatan Gigi Berbasis Android," J. Teknol. Inf. dan Komun., vol. 9, no. 1, pp. 59-68, 2019.

[3] A.S. Rosa.. dan Shalahudin. M. Rekayasa Perangkat Lunak Terstruktur dan Berorientasi Objek, Bandung: Informatika, 2016.

[4] Rakhman, A., \& Rais, R. (2020). Analisa Pakan Burung Otomatis Menggunakan Arduino Berbasis Internet Of Things. Syntax Literate; Jurnal Ilmiah Indonesia, 5(5), 18-25.

[4] Enterprise, Jubile. Mudah Membuat Aplikasi Absensi dengan Java, 
Yogyakarta : PT Elex Media Komputindo, 2015.

[5] Safaat H, Nazruddin. Rancang Bangun Aplikasi Multiplatform, Bandung: Informatika, 2015.

[6] Irvan Rizkiansyah. 2013. Pengembangan Aplikasi Pembelajaran Interaktif Teknik Bermain Piano Berbasis Multimedia Di Lembaga Kursus Musik "Ethnictro" Yogyakarta.

[7] Apif Susanti dan Dwi Wahyu Prabowo. E-Commerce Pada Toko My Digital. 